NASA/TM-2003-212031

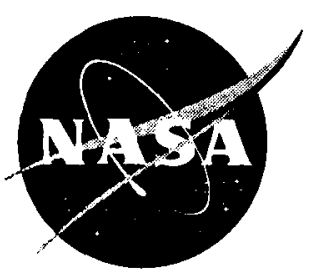

\title{
A Powerful Friendship: Theodore von Kármán and Hugh L. Dryden
}

Michael Gorm

NASA Dryden Flight Research Center

Edwards, California 


\section{The NASA STI Program Office...in Profile}

Since its founding, NASA has been dedicated to the advancement of aeronautics and space science. The NASA Scientific and Technical Information (STI) Program Office plays a key part in helping NASA maintain this important role.

The NASA STI Program Office is operated by Langley Research Center, the lead center for NASA's scientific and technical information. The NASA STI Program Office provides access to the NASA STI Database, the largest collection of aeronautical and space science STI in the world. The Program Office is also NASA's institutional mechanism for disseminating the results of its research and development activities. These results are published by NASA in the NASA STI Report Series, which includes the following report types:

- TECHNICAL PUBLICATION. Reports of completed research or a major significant phase of research that present the results of NASA programs and include extensive data or theoretical analysis. Includes compilations of significant scientific and technical data and information deemed to be of continuing reference value. NASA's counterpart of peer-reviewed formal professional papers but has less stringent limitations on manuscript length and extent of graphic presentations.

- TECHNICAL MEMORANDUM. Scientific and technical findings that are preliminary or of specialized interest, e.g., quick release reports, working papers, and bibliographies that contain minimal annotation. Does not contain extensive analysis.

- CONTRACTOR REPORT. Scientific and technical findings by NASA-sponsored contractors and grantees.
- CONFERENCE PUBLICATION.

Collected papers from scientific and technical conferences, symposia, seminars, or other meetings sponsored or cosponsored by NASA.

- SPECIAL PUBLICATION. Scientific, technical, or historical information from NASA programs, projects, and mission, often concerned with subjects having substantial public interest.

- TECHNICAL TRANSLATION. Englishlanguage translations of foreign scientific and technical material pertinent to NASA's mission.

Specialized services that complement the STI Program Office's diverse offerings include creating custom thesauri, building customized databases, organizing and publishing research results...even providing videos.

For more information about the NASA STI Program Office, see the following:

- Access the NASA STI Program Home Page at http://www.sti.nasa.gov

- E-mail your question via the Internet to help@sti.nasa.gov

- Fax your question to the NASA Access Help Desk at (301) 621-0134

- Telephone the NASA Access Help Desk at (301) 621-0390

- Write to:

NASA Access Help Desk

NASA Center for AeroSpace Information

7121 Standard Drive

Hanover, MD 21076-1320 
NASA/TM-2003-212031

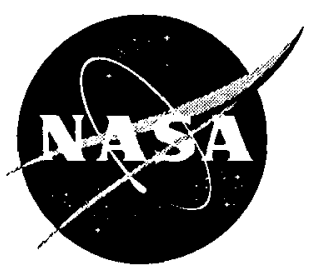

\section{A Powerful Friendship: Theodore von Kármán and Hugh L. Dryden}

Michael Gorn

NASA Dryden Flight Research Center

Edwards, California

National Aeronautics and

Space Administration

Dryden Flight Research Center

Edwards, California 93523-0273 


\section{NOTICE}

Use of trade names or names of manufacturers in this document does not constitute an official endorsement of such products or manufacturers, either expressed or implied, by the National Aeronautics and Space Administration.

Available from the following:

NASA Center for AeroSpace Information (CASI) 7121 Standard Drive Hanover, MD 21076-1320

(301) 621-0390
National Technical Information Service (NTIS) 5285 Port Royal Road Springfield, VA 22161-2171

(703) $487-4650$ 


\section{ABSTRACT}

During their long personal friendship and professional association, Theodore von Kármán (1882-1963) and Hugh L. Dryden (1898-1965) exercised a pivotal if somewhat elusive influence over American aeronautics and spaceflight. Both decisive figures in organizing scientists and engineers at home and abroad, both men of undisputed eminence in their technical fields, their range of contacts in government, academia, the armed forces, industry, and professional societies spanned the globe to an extent unparalleled then as now. Moreover, because they coordinated their activities closely, their combined influence far exceeded the sum of each one's individual contributions. This paper illustrates their personal origins as well as the foundations of their friendship, how their relationship became a professional alliance, and their joint impact on the world of aeronautics and astronautics during the twentieth century.

\section{DIFFERENT WORLDS}

In other times, the lives of Prof. Theodore von Kármán and Dr. Hugh L. Dryden might not have intersected. Only in the turmoil and flux of the twentieth century could they have met, let alone become friends. Theodore von Kármán-still known nearly 40 years after his death for his personality, his technical achievements, as well as his institution-building-remains one of the most influential individuals in the history of aeronautics. Hugh L. Dryden, although not as indelibly remembered as Kármán, remains a man of the highest scientific caliber, a person of quiet counsel who influenced the careers and lives of countless associates and who transformed innumerable air and space projects. The two arose from utterly different circumstances, but together did much to re-shape the world of flight.

Kármán grew up in a cultured, solidly middle class Hungarian home. His family lived in a cluster of comfortable apartments in the graceful city of Budapest, then one of the two capitols of the Austro-Hungarian Empire. On his mother's side, his ancestors had been scholars, scientists, and prominent Rabbis, including the sixteenth century mathematician Yehuda Loew Ben Bezalel, friend of the Danish astronomer Tycho Brahe. In contrast, Kármán's father-Maurice von Kármán-matured in a family of tradesmen, his father serving as a tailor to Hungarian noblemen. A philosophy and education professor at the University of Budapest, the elder Kármán drove himself to succeed, ultimately earning a title of nobility for his reforms of the Hungarian educational system, which he modeled on the German gymnasia. Although Jewish, the Kármáns lived a thoroughly assimilated and cosmopolitan life in their native Budapest.

Maurice and Helen's third son-named Todor, or "gift from God"-certainly showed early and obvious signs of intellectual attainment. Indeed, at the age of only six, his brothers noticed that he had the capacity to multiply five and six digit figures in his head, with unerring accuracy. Yet, his stern father banned this activity, telling Todor that for the foreseeable future, he must concentrate on the humanities. Maurice feared that his son's educational development might be arrested if he pursued only technical subjects, so he directed him into history, literature, and the arts, leaving math and science for future years. This training left Kármán a legacy of broad learning, and it prepared him well for his university career. Unfortunately, his father suffered a nervous breakdown about the time Theodore intended to enter college, and instead of attending one of Europe's great centers of learning, his family's finances and the fragile state of his father's health conspired to confine him to Budapest. Here he went to the Royal Joseph Technical University, concentrating on an engineering curriculum under the highly respected Professor Donat Banki. Eventually, he did receive a doctorate in fluid mechanics from Göttingen, the great German 
university, studying with Professor Ludwig Prandtl, one of the field's founders. However, Kármán never really adapted himself to Göttingen's formality or to Prandtl's reserve. Indeed, his formative work under Banki represented at least an equal scholarly influence; rather than concentrate on purely theoretical research, he developed a strong taste for applied physics, applied mathematics, and engineering. In fact, over the years he and Prandtl developed something of an intellectual rivalry, one that eventually put Hugh Dryden in Kármán's path. ${ }^{1}$

In contrast to Kármán's distinguished father and ancestors, the forebears of Hugh Dryden showed no sign of fame. Their origins are traced to Scotland, in the vicinity of Edinburgh. A portion of the family moved to the colony of Maryland in 1682 seeking religious toleration in the face of Charles II's imposition of Anglican bishops on the Presbyterian Church. The Drydens settled in Somerset and Worcester Counties at the southern tip of the state. Townsmen in the old country, they rapidly accustomed themselves to farming life in the New World, although many continued to pursue skilled trades like shipwright and shoemaker. For the most part, they settled near the quiet Pocomoke River, which flows into Chesapeake Bay. During the nineteenth century, many of the Drydens embraced Methodism. For two hundred years, then, the Drydens-people of average wealth and station-worked at their occupations, paid taxes, and produced offspring.

But if their lives differed in general, Samuel Dryden and Maurice von Kármán both shared a desire to better their fortunes through education. Samuel evidently possessed exceptional talents in mathematics and his teachers encouraged him to pursue a career in the field. Accordingly, he earned a teaching certificate with his High School Diploma and settled in the town of Pocomoke City, became a teacher, and shortly thereafter, a Vice Principal. He seemed destined for a life of at least local distinction. But here the similarity with Maurice von Kármán ended. After seven years in the classroom, Samuel Dryden left abruptly, removed his family from Pocomoke City, and relocated to a rural crossroads known as West Postoffice, Maryland. Perhaps the redirection occurred because of his reputed hot temper; perhaps it reflected his desire to better provide for his family. In any event, Samuel and his brother opened a general store in West Postoffice in 1900. Unfortunately, it failed in the Panic of 1907, forcing Samuel, his wife Zenovia, and their two sons to leave Southern Maryland for good.

Zenovia Dryden gave birth to her first son on July 2, 1898. She and Samuel named him for a regionally popular Methodist clergyman by the name of Hugh Latimer Elderdice. Hugh Latimer Dryden entered the world with some distinct advantages, as well as some equal disadvantages. On the positive side, he lived among a sea of relatives-gregarious and often inclined toward music - and witnessed the birth of no fewer than 28 paternal first cousins as he matured. Moreover, his mother, known by the nickname Nova, nurtured in her first born some of her own qualities: patience, modesty, and discernment. If young Hugh favored his mother's temperament, he showed glimpses of the mental acuity of his father. Precocious, he could read by age four, and by eight had already begun to master the fifth grade curriculum. But as a boy and young man Hugh Dryden also lived with some less than satisfactory conditions. Try as he might, Samuel Dryden failed to provide his family with more than the bare essentials. Regarded as brilliant by his neighbors and known for acts of charity and generosity, he nonetheless lacked the toughness for commerce. In addition, the humble one-room schoolhouse in West Postoffice provided a poor preparation for a student of Hugh's promise.

When the Drydens left West Postoffice in 1907, they settled in Baltimore, then a thriving port with a heavy influx of immigrants. The big city represented opportunity for Hugh, but the end of ambition for his father. Samuel Dryden took a job with the Baltimore United Railways and Electric Company as a. 
streetcar conductor, and remained one the rest of his working life. While steady, his income just met the household's needs. Hugh, on the other hand, found a new world. He became a Baltimore Sun paperboy, started intermediate school at age nine, and completed it at 12-about three years younger than his classmates. In between, he worked part-time to augment the family income: on the assembly line of the United Biscuit Company, sorting packages for an express delivery service, and in the hard labor of a canning factory.

Just about the time of his graduation, aviator Hubert Latham accepted a challenge offered by the Baltimore Sun to fly over the city for a purse of $\$ 5,000$. Twelve-year-old Dryden and his mother watched as Latham flew loops over the Sun building, an event that captured his imagination and first piqued his curiosity about flight. After graduation he entered Baltimore's finest High School, called Baltimore City College. Here his talent for mathematics became unmistakable. In 1913 he graduated first in a class of 172, won the Peabody Prize for Mathematics, completed his studies in three years rather than the customary four, and became the youngest ever to graduate from the school. Finally, during fall 1913-at the age of 15-he entered Baltimore's great university founded by the Quaker merchant Johns Hopkins with a full undergraduate scholarship. At Hopkins, he encountered one of the great synthesizers in American physics, Professor Joseph Ames, chair of the department and later president of the university. Ames exercised a profound, almost parental influence on Dryden. He guided him through his Bachelor's degree (in three years), and afterwards helped him attain his Masters in applied physics. Ultimately, Hugh Dryden earned the doctorate in physics in 1919 at age 20, the youngest Hopkins graduate to earn a Ph.D. His dissertation concerned the scale effects of air flowing around columns perpendicular to the wind, a subject of real importance in the fledgling field of aerodynamics. The conditions under which he earned his degree affected the remainder of his career. ${ }^{2}$

\section{A CHAIN OF EVENTS}

During his long working life, Theodore von Kármán held just two academic posts. After a false start, in 1913 (at the age of 31), he became the Director of the Aachen Aerodynamics Institute at the Aachen Technical University. Unlike Gottingen, whose rules and rigidity displeased him, Aachen offered a cosmopolitan atmosphere more like his native Budapest. Here, close by France and at the confluence of the German, Dutch, and Belgian borders, Kármán fashioned a little known institute into one of international renown, in some ways the rival of that of his teacher, Prandtl. He accomplished this feat by winning the support, the friendship, and the consulting fees of such industrialists as Junkers, Zeppelin, and Fokker. He hired able faculty. He transformed the open wind tunnel design of his predecessor, making it into a more efficient closed circuit model. He threw himself into teaching, which he loved, and taught in the style of Donat Banki; that is, he used simple examples from life to illustrate complicated physical phenomena. He taught his students as much during parties in his home and in the cafes of Aachen as he did in the classroom. Finally, he burnished the reputation of the institute by adding to his earlier, trailblazing discovery of the Kármán Vortex Street with three new technical achievements: a moveable trailing edge for airfoils, a restatement of Prandtl's boundary layer theory, and a reformulation of the boundary layer equations (enabling comparisons between theory and experiment).

In the midst of these activities, Theodore von Kármán saw four years of service in the Austro-Hungarian army during the First World War. Commissioned an officer and made the director of the research department of the Austro-Hungarian Aviation Corps, he learned some important lessons; 
about how to organize large science and engineering projects, how to obtain and maintain budgets, and how to collaborate with generals and admirals.

At the end of the war, he returned to Aachen and decided to involve himself in a lifelong interest, international scientific cooperation. Such an objective faced formidable obstacles after four years of incomparably bitter warfare. His father had always preached the value of internationalism, and Kármán never had any problem persuading English, German, French, and Italian scientists to mingle at his home in Vaals, Holland, even in the postwar climate. Therefore, in 1921, he issued a call for papers for the world's First Congress on Aerodynamics and Hydrodynamics, to be convened in Innsbruck, Austria, in 1922. He and his sister Josephine defrayed the costs personally. It succeeded in attracting the leading scholars and Kármán delivered a seminal talk on the surface friction of fluids, one in which he invited an international discussion about a general theory of turbulence. He followed it in 1924 by organizing the First International Congress of Applied Mechanics, held in Delft, Holland and this time spoke about laminar flow and turbulence, providing a partial answer to the challenge he issued two years earlier.

Strangely and unexpectedly, the Delft Congress ultimately occasioned the personal and professional association of Kármán with Hugh L. Dryden. At the Congress, the President of the California Institute of Technology Robert Andrews Millikan met the Hungarian for the first time. Almost immediately, the canny Millikan realized he had found a man who could lead one of his most prized projects: a Caltech aeronautics institute funded by the famous Guggenheim Fund for the Promotion of Aeronautics. Alert to the crucial role Caltech might play in the growth of a local aircraft industry-an industry nurtured by good year-round weather, cheap power for wind tunnels, and relatively uncrowded skies-Millikan courted Kármán just as he had the Guggenheims. Kármán certainly liked the princely salary offered by Millikan, but he also felt betrayed by the German university system, which, he believed, denied him promotion due to his Jewish origins. The result: in 1930 Theodore von Kármán, his sister, and his mother left Vaals and took up residence in Pasadena, California, a short distance from Caltech. ${ }^{3}$

Now resident at least on the same continent, the chances of Kármán and Dryden meeting improved. While the Hungarian and his kin settled into life in the West, Hugh Dryden continued to progress on the other side of the country, near his native Baltimore. Actually, Dryden earned his doctorate while he worked. Towards the end of the First World War, his mentor Joseph Ames won a position for him at the National Bureau of Standards (NBS), located in suburban Maryland. After Ames's initial introduction, Dryden's career took root. After working briefly with munitions gauges, he transferred to the NBS's newly opened Aerodynamics Section, equipped with one of the country's early wind tunnels. Because Ames had just been appointed to a seat on the fledgling National Advisory Committee for Aeronautics (the NACA), which met in Washington, D.C., he found it convenient to offer courses to Dryden and some of the others he had placed at NBS. Meantime, in 1920-at age 22-Dryden became Chief of the Aerodynamics Section, in charge of the Bureau's wind tunnel research. Perhaps more importantly, during the same year the reserved young scientist married a vivacious woman named Libby Travers whom he had met years before at church in Baltimore. The couple relocated from Baltimore to a modest duplex inside Washington, D.C.'s verdant Rock Creek Park, and began to raise a family.

Dryden then launched his career at the Bureau in earnest. During the first six years he began a research collaboration with Dr. Lyman J. Briggs, a mentor and friend who eventually became director of the NBS. Dryden decided to investigate transonic flight, a subject far ahead of its time and a theoretical curiosity in an age when the winner of the 1920 Schneider Cup Air Race flew at 107 miles per hour. It nonetheless established his reputation. Together with Briggs, Dryden concentrated on the problem of 
compressibility. During the early 1920s, the phenomenon manifested itself in the behavior of propeller blade tips. Attached to aircraft engines of increasing power, the blades rotated at transonic and supersonic speeds, resulting in unexplained boundary layer separation and buffeting. Because no existing wind tunnels could generate sufficiently fast airflows, Dryden and Briggs traveled to large compressor plants to conduct their investigations. Here they made some of the earliest experimental observations about aerodynamic drag approaching the speed of sound, about the effects of compressibility on aerodynamic lift and drag, and about airfoil design modifications for propeller manufacturers. Several seminal research papers followed. Their experiments also prompted the aeronautics community to entertain the necessity of wind tunnels capable of transonic airflows.

During the late 1920s, Dryden became associated even more closely with wind tunnel design. At one point, he and an assistant at the Bureau named Arnold Kuethe discovered an astonishing discrepancy between their wind tunnel data and that generated by the one located at the Washington (D.C.) Navy Yard. The same airship model mounted in the two machines yielded data at 100 percent variance. Dryden reasoned that incidental turbulence inside one or both of them must have caused the odd readings. To sort out the airflows, he and Kuethe placed a modified hot wire anemometer in their tunnel, instrumenting it to measure rapid air fluctuations. They discovered that even slight variations in turbulence inside tunnels could result in large experimental divergences. Using this device, Dryden developed criteria by which to diminish turbulence in existing tunnels, and to further reduce it in the construction of new ones. The increase in accuracy benefited Dryden's own research and reputation. By making the Bureau's machine capable of more exacting and consistent readings, he succeeded in isolating the workings of the boundary layer, in particular the transition from laminar to turbulent flow, thus enabling Dryden to verify experimentally Prandtl's 1907 boundary layer theory.

At this point, the name Hugh L. Dryden became well known in aeronautics circles. The American Association for the Advancement of Science elected him a member, as did the Washington Philosophical Society. He won promotion on the job, becoming Chief of the Mechanics and Sound Division, which included his own Aerodynamics Section. He also found himself sought out by some of the giants of the aeronautics profession. Yet, Dryden did not seek such recognition actively. Diligent, reserved, and self-effacing, he worked quietly on his own projects, guided those of his subordinates, and earned a reputation for effectiveness. His devout adherence to the Methodist faith may have contributed to his distaste for self-promotion. Nonetheless, the importance of his research commanded attention. ${ }^{4}$

\section{THE EVOLUTION OF A FRIENDSHIP}

Theodore von Kármán took notice of Hugh Dryden during the early 1930s. The path to Dryden originated with Ludwig Prandtl. The strain in the teacher-student relationship manifested itself as an intellectual competition between the two men. During the late 1920s both of them struggled to fashion a universal law of turbulence. Prandtl held a clear lead. A brilliant theorist as well as a fastidious experimentalist, he possessed decades of Gottingen's research data from which to draw. In contrast, Kármán took up the challenge in his own way, relying on his intuition and mathematical approximations to unlock this formidable problem. Prandtl struck first with his 1926 "Mixing Length Concept" to describe friction at the molecular level. Kármán responded at the Fourth International Congress of Applied Mechanics in Stockholm in 1930. He presented a paper entitled "Mechanical Similarity in Turbulence," which succeeded in encapsulating Prandtl's theory and experiments on skin friction, suggesting that at least partial order existed inside the mechanisms of turbulence. But the race continued: 
who would be first to demonstrate the formula experimentally? Kármán had read about Hugh Dryden's ingenious modifications of the hot wire anemometer that so simply and effectively reduced the incidental turbulence found in tunnels and improved accuracy. He contacted Dryden to learn its techniques. Dryden dispatched his assistant, Arnold Kuethe, to the Caltech Laboratory and using the new approach, Kármán's team took measurements that confirmed his hypothesis.

Hugh Dryden and Theodore von Kármán certainly met-if not for the first time-at the Fifth International Congress of Applied Mechanics in 1934. Here Dryden-in his first trip outside the U.S.-presented an important paper called "Boundary Layer Flow Near Flat Plates," one that added significantly to the understanding of the mechanics of smooth motion and further cemented his reputation. They subsequently encountered one another at the meetings of the newly formed Institute of the Aeronautical Sciences in New York. Kármán served as a founding member of the Institute, and indeed first revealed the confirmation of his theory of turbulence at one of their meetings. During this period, they also helped inaugurate and sat together on the board of editors of the Quarterly of Applied Mechanics. Dryden, meanwhile, won recognition for his own achievements when in 1938 the Institute invited him to deliver the annual Wilbur Wright Lecture, the first American so honored. The Bureau of Standards rewarded his rising eminence by naming him Chief Physicist. Thus, as the two men began working more closely, Dryden's star continued to rise, in time becoming as bright as the Hungarian's.

Whatever elusive ingredients of personality, character, and intellect coalesce to form deep and permanent friendships, these traits existed in the Kármán-Dryden relationship. Superficially, they appeared to be opposites in many respects. Kármán loved to be surrounded by people-his family, friends, colleagues, and students. The parties at his homes in Vaals, and later at Marengo Drive in Pasadena, California resounded with an earthy gaiety, rather than academic stuffiness. Actresses, students, clergymen, scientists, and military officers constituted some of the favored personalities and reflected the catholic tastes of the host. Kármán also liked to drink, especially plum brandies and martinis. Indeed, a month or two before his death, when he had become quite ill, he met with a few former students in Paris for dinner. Like the others, he had many martinis that night; but when they parted, only he seemed unaffected by the intake. In addition, Theodore von Kármán exemplified European cosmopolitanism. Able to speak six languages well-although he often said that he spoke the universal scientific language, Bad English-he looked like a man of the world outfitted with a beret, cigars, and the pronounced accent that Hugh Dryden called strong enough for "commercial purposes." (After ordering tickets at a train station for Schenectady, the clerk behind the glass handed him ones for Kansas City). Not surprisingly, his worldly outlook affected his religious views. He believed in international cooperation and universal brotherhood and certainly accepted broadly the notion of God. "My father taught me to believe in God," he said in his memoirs, "saying that science deals only with consistency, not with truth." Still, although Jewish by birth, he practiced no particular faith. On his death, a Catholic priest who ministered to the Hungarian community in Los Angeles lead a memorial service in his home; a Rabbi officiated at his burial at Hollywood Cemetery. Finally, Kármán felt that despite his acknowledged contributions to scholarship, his best work occurred as a teacher. A performer at heart, the classroom gave him a stage. In his lectures he made it a practice to present mathematical problems he had not yet solved, enabling his students to watch as he worked out the answers spontaneously, in the moment. If he became stuck, he customarily took a handkerchief from his pocket, wound it tightly, placed one end in the corner of his mouth, the other in his hand, and twisted it as he stood looking at the blackboard. When the answer finally came to him and he wrote it in for the audience to see, they sometimes broke into applause at the novelty and dexterity of his solutions. ${ }^{5}$ 
Hugh Dryden's temperament offered a stark contrast to Kármán's. A natural introvert, Dryden nonetheless learned to relax at social functions, even though neither he nor his wife especially liked going to or giving parties. Yet, he still needed to make the right impression, so he developed the habit of asking bartenders for water and ice in a highball glass, sipping it as he circulated, and hiding the fact that it contained no alcohol. Dryden presented himself well, in nicely tailored business suits, and he possessed a quiet sophistication. He spoke in a clear, distinct, tenor voice and although he did not exude charisma, he did project extraordinary intellect, combined paradoxically with surprising personal warmth.

Dryden's religious faith played a profound role in his life. As a teenager he felt drawn towards the ministry. But Methodist seminaries did not accept applications from 15 year olds, so he enrolled in Johns Hopkins instead. He nonetheless served as a lay Methodist minister his entire adult life and his surviving sermons suggest a deep-seated spirituality and a theology based purely on faith. If his preaching offers any clues, Hugh Dryden might have made a very fine teacher. But his inclinations lay elsewhere. Unlike Kármán, who loved to lecture, Dryden never relished being the center of attention and although he possessed some of the qualities of a good teacher, such as patience and persistence, it is certainly no accident that he worked as a civil servant, a researcher, and a science manager his entire career.

It is easy to find the differences between these two eminent scientists. But less apparent, and at the same time more telling, are the similarities. Both liked to laugh. Kármán's humor usually consisted of short, bawdy jokes laced with double entendre, frequently presented in remarks after banquets and other gatherings. Dryden's drew his inspiration from life, favoring deadly accurate imitations of co-workers or fellow researchers. Both admired the opposite sex, but in entirely different ways. By present standards, Kármán's anecdotes (and actions) sometimes exceeded the bounds of judgment and propriety. In contrast, Dryden's interest left more to the imagination. Apparently, he often assumed the task of grocery shopping due to his wife's poor health. Usually, his younger daughter Nancy accompanied him, and when they got inside the supermarket, he asked her to take part of the list and fill it. Meantime, he headed for the meat counter where, as virtually the only man there, he got all of the attention of the women making their selections. Nancy Dryden called it "being single with one eye."

Dryden and Kármán both believed wholeheartedly in the importance of international scientific cooperation as an instrument of peace and of technical advancement. Kármán, of course, began his own initiatives during the 1920s. Dryden joined him during the 1930s and, in time, not only became the equal of his mentor, but surpassed him. During the late 1950s, President Eisenhower appointed Dryden a representative to the United Nations Ad Hoc Committee on the Peaceful Uses of Outer Space. This assignment lead to his role as chief negotiator with Soviet Academician Anatoly Blagonravov, a dialogue that resulted in limited but unprecedented cooperation on meteorology, communications, and magnetic field research. "I am persuaded," wrote Dryden at the time, "that there are very great values to the United States in this cooperation."

Other parallels existed between these individuals, but perhaps the most significant one involved their fathers. Different as they might have been in social standing, education, and culture, both Maurice von Kármán and Samuel Dryden possessed keen intelligence. More important, both suffered profound, and to a large degree self-inflicted reversals early in their careers-Maurice due to his excitability and eventual nervous breakdown, Samuel due to hot headedness and failure in business. The ill-effects of such behavior must have been obvious to young Dryden and Kármán, who felt the consequences as they matured. Equally apparent to them must have been the essential qualities necessary to fashion their own careers: patience, tolerance, and the capacity to collaborate with others. Both practiced these arts with 
consummate skill and no doubt recognized and appreciated these qualities in the other. This unique similarity explains more than any other factors how they forged such a durable and productive personal and professional alliance. ${ }^{6}$

\section{A PROFESSIONAL COLLABORATION}

Not surprisingly, Dryden's and Kármán's most admired and influential joint achievement occurred in the international arena. It originated with an intense and fruitful collaboration between Theodore von Kármán and General of the Army Air Forces Henry H. Arnold. The two men had gotten to know one another during the mid-1930s when Arnold commanded March Field, California, in close proximity to Caltech. They established a friendship based on the Hungarian's willingness to instruct Arnold about the latest aeronautical developments. As the Second World War approached, Arnold prevailed upon Kármán to devote an increasing proportion of his time to advising him and his staff about the future of flight. On one occasion, Kármán flew to Dayton, Ohio, on the invitation of General Frank Carroll, who asked hirn to spend a weekend determining whether the speed of sound could be achieved with existing technology. Kármán's affirmation set the wheels in motion for the X-1 aircraft.

During summer 1944, when it seemed clear that the allies finally held the key to victory, Arnold contacted Kármán for the biggest assignment yet. The general asked for a complete, global review of the technologies underpinning the wartime advances in aeronautics and missilery. To achieve this end, he asked Kármán to travel wherever necessary to obtain data first hand. More daunting, Arnold also wanted a comprehensive narrative blueprint for future development based on the most recent discoveries. Kármán had just undergone surgery for intestinal cancer, but rose to the challenge. Realizing that this project would require many hands, he needed to choose an array of scientists with specialties appropriate to the survey. He turned first to Hugh Dryden to be his partner and deputy. Dryden had devoted most of the war to managing a Navy project of profound importance for future guided missile development known as the Bat, a radar-guided gravity bomb capable of self-correction in flight. It proved to be successful operationally during the Battle of Okinawa, in which the Bat sank a significant amount of Japanese tonnage.

Fresh from the experience of managing a large federal research program, Dryden joined his friend in December 1944, and for the better part of a year assisted him in fulfilling Arnold's enormous task. They met in the recently completed Pentagon building and together wrote down the names of some of the most eminent American scientists to recruit for the project. After several months of discussion, they selected six researchers to help Kármán and Dryden organize the team, including Kármán's brilliant student Hsue-shen Tsien for rocketry and Dr. Louis Alvarez for radar. The more difficult job involved picking subject area experts to fill the technical panels that actually converted the raw data gleaned in the U.K., France, Germany, Italy, the Soviet Union, Japan, and other places into comprehensive reports and forecasts. They chose 21 individuals (almost two-thirds from academia, of which a third held positions on the Caltech faculty). 7

The group departed for Europe in April 1945 prepared to assess the current state of international aeronautics. In London, Kármán and Dryden donned uniforms bearing the simulated ranks of major general and colonel, respectively. They then traveled to Paris, the jumping-off point of the mission and from there to the German border. They drove to an aeronautics laboratory near Braunschweig, in the village of Völkenrode, concealed from public view in a setting of forests and farms and just lately uncovered by U.S. forces. Dryden and Kármán interviewed some of the leading German scientists about 
their guided missile and jet propulsion research and amassed some 1,500 tons of materials relating to swept-wing aerodynamics and highspeed human physiology. The two friends then divided forces. Dryden and part of the group went to Munich, where he conducted intense interrogations about the V-1 and V-2 missiles with Dr. Wernher von Braun, his boss General Walter Dornberger, and some 400 scientists who had been relocated from the Peenemunde rocket facility. Dryden then returned home after re-tracing his steps through Germany, France, and England. Kármán, meanwhile, went farther afield. He went first to Aachen to see his former aerodynamics institute, which had been reduced to rubble by the allies. He journeyed on to Göttingen, which had been spared from devastation, and found his old mentor still in residence. The two of them had several tense encounters, mainly about Prandtl's alleged collaboration with Nazi officials. Finally, before returning to Washington, Kármán flew to Moscow, where Soviet Marshal Stalin feted him at a state dinner. Despite the pomp of the welcome, it soon became clear that the Soviet scientists had not been cleared to discuss their wartime research.

Worn from his rigors, Kármán returned to the Pentagon in July, after which he and Dryden drafted a preliminary report about the existing state of aeronautics entitled Where We Stand, one of the most sweeping surveys ever attempted. Based upon the data collected to date, Kármán and Dryden arrived at some startling conclusions. They believed that future aircraft had the potential to fly far beyond the speed of sound; that highly destructive payloads had the capacity to be launched from thousands of miles distance; and that advanced targeting and navigation offered the possibility of full flight operations in darkness and bad weather.

After presenting Where We Stand to the general, the group scattered again, going first to Europe, then to Asia, in order to gather materials for the full-sized forecast requested by Hap Arnold. But Dryden stayed back. He and Kármán decided that as the materials poured in by cable from the traveling scientists, Dryden needed to be in Washington to assemble the final report. Meantime, Kármán's team-newly named the Army Air Forces Scientific Advisory Group-boarded Arnold's personal C-54 transport and embarked on a whirlwind world tour that lasted much of fall 1945. Led by their chief, they visited scientists in the U.K., France, Holland, Switzerland, Sweden, and Italy. But exhaustion at last caught up with Kármán. He decided to send the rest to the Orient-to Australia, India, China, and Japan—while he checked into the luxurious Prince of Wales Hotel in Paris to recover.

Dryden and a restored Kármán spent the month of November 1945 collaborating on the final report by transatlantic cable. If Kármán carried the main work during the earlier part of the project, Dryden bore the burden at the end, assuming the heavy responsibility of imposing technical accuracy, consistency, and unifying themes on its many parts and authors. Kármán did, however, contribute an extraordinarily far-seeing introductory essay entitled Science, the Key to Air Supremacy. Meanwhile, Dryden's long march lasted into early December. Finally, the sprawling forecast arrived on General Arnold's desk on December 15, 1945. Called Toward New Horizons, this seminal collection of 33 essays written by 25 scientists served not merely as a blueprint for American survival in an age of potentially devastating attack from the air, but as a guide for civilian aeronautics - and indeed space research-for decades to come. It looked to the future under broad headings such as aerodynamics and aircraft design, powerplants, fuels and propellants, radar, weather and flight, and aviation medicine. Toward New Horizons also advised the Army Air Forces to become more scientifically oriented and to reorganize in order to take advantage of the recent and future breakthroughs in aeronautics. But perhaps more importantly, Hugh Dryden and Theodore von Kármán offered military leaders and industrialists (as well as younger scientists and engineers just leaving military service) a clear agenda for postwar research, one that offered direction to generations of aerospace practitioners. ${ }^{8}$ 


\section{AN ENDURING PARTNERSHIP}

Toward New Horizons did not represent the last public collaboration between Dryden and Kármán. During the early 1950s Kármán suggested to Air Force Chief of Staff General Hoyt Vandenberg that NATO establish an advisory panel—not unlike another Kármán creation, the Air Force Scientific Advisory Board-to infuse the Atlantic Alliance with the latest technical knowledge. Called the NATO Advisory Group for Aeronautical Research and Development, or AGARD, it included Hugh Dryden among its most active organizers and participants. AGARD planning sessions and meetings frequently brought the two old friends together during the 1950s.

Finally, the close bond between the two men continued even after the death of Theodore von Kármán in May 1963. Upon his passing, Hugh Dryden became Kármán's chief eulogist, writing the bulk of the memorials, tributes, and recollections that appeared in print. In them Dryden remembered not only the Hungarian's immense scientific contributions, his teaching, and his fostering of international scientific: cooperation, but the human qualities that made him so different from others. Perhaps not paradoxically, several of the very traits Dryden emphasized-compassion, generosity, and tolerance-united these two. quite different souls. ${ }^{9}$ 


\section{REFERENCE NOTES}

1. Theodore von Kármán with Lee Edson, The Wind and Beyond: Theodore von Kármán, Pioneer in Aviation and Pathfinder in Space (Boston, Toronto: Little, Brown, 1967), 13-34; Michael H. Gorn, The Universal Man: Theodore von Kármán's Life in Aeronautics (Washington and London: Smithsonian Institution Press, 1992), 1-13.

2. Chapter 1 (draft) of a biography of Hugh L. Dryden by the author, filed in the NASA Dryden Flight Research Center Historical Reference Collection; Michael H. Gorn, Hugh L. Dryden's Career in Aviation and Space (NASA Monograph in Aerospace History \#5) (Washington, D.C.: NASA History Office, 1996), 1-2.

3. Kármán, Wind and Beyond, 71-90, 103-129, 140-146; Gorn, Universal Man, 33-54.

4. Gorn, Hugh L. Dryden's Career, 3-5.

5. Kármán, Wind and Beyond, 23-24 (quoted passage, 23), 134-140; Gorn, Universal Man, 60-69, 153-155; Gorn, Hugh L. Dryden's Career, 3-4.

6. The assessment of Hugh Dryden's personality is based on research for a forthcoming book by the author entitled To Ride the Air: NASA's Hugh L. Dryden. See also the draft of Chapter 1 referenced in note 2. In addition, see Gorn, Hugh L. Dryden's Career, 4, (quoted passage, 14), 17 and Gorn, Universal Man, 9, 35-36, 147. For a statement of Hugh L. Dryden's religious views, see reprinted in Hugh L. Dryden's Career "The Importance of Religion in American Life," March 1950, 123-130.

7. Michael H. Gorn, Harnessing the Genie: Science and Technology Forecasting for the Air Force, 1944-1986 (Washington, D.C.: Office of Air Force History, 1988), 11-23; Gorn, Hugh L. Dryden's Career, 5-6.

8. Gorn, Harnessing the Genie, 23-42; Gorn, Hugh L. Dryden's Career, 6-7.

9. Two examples of Hugh Dryden's memoirs of Kármán are: "Theodore von Kármán, 1881-1963," in the Biographical Memoirs of the National Academy of Sciences (1965) and "The Contributions of Theodore von Kármán: A Review," in Astronautics and Aerospace Engineering (July 1963). Gorn, Universal Man, 132-134. 
Public reporting burden for this collection of information is estimated to average 1 hour per response, including the time for reviewing instructions, searching existing data sources, gathering and maintaining the data needed, and completing and reviewing the collection of intormation. Send comments regarding this burden estimate or any other aspect of this collection of information, including sugestions for reducing this turden, to Washington Headquarters Services, Directorate for Information Operations and Reports, 1215 Jefferson Davis Highway, Suite 1204, Arlington, VA 22202-4302, and to the Office of Management and Budget, Paperwork Reduction Project (0704-0188), Washington, DC 20503.

\begin{tabular}{|l|l|l|}
\hline 1. AGENCY USE ONLY (Leave blank) & 2. REPORT DATE & $\begin{array}{l}\text { 3. REPORT TYPE AND DATES COVERED } \\
\text { Technical Memorandum }\end{array}$ \\
\hline
\end{tabular}

4.TITLE AND SUBTITLE

A Powerful Friendship: Theodore von Kármán and Hugh L. Dryden
953-20-00-GA-TT-00-000

8. PERFORMING ORGANIZATION REPORT NUMBER

H-2545

P.O. Box 273

Edwards, California 93523-0273
10. SPONSORING/MONITORING AGENCY REPORT NUMBER

NASA/TM-2003-212031

Washington, DC 20546-0001

\section{SUPPLEMENTARY NOTES}

Presented at the 41st AIAA Aerospace Sciences Meeting Exhibit, Reno, Nevada, January 6-9, 2003, AIAA2003-0289.

12a. DISTRIBUTIONAVAILABILITY STATEMENT 12b. DISTRIBUTION CODE

Unclassified-Unlimited

Subject Category 99

This report is available at http://www.dfrc.nasa.gov/DTRS/

13. ABSTRACT (Maximum 200 words)

During their long personal friendship and professional association, Theodore von Karman (18821963) and Hugh L. Dryden (1898-1965) exercised a pivotal if somewhat elusive influence over American aeronautics and spaceflight. Both decisive figures in organizing scientists and engineers at home and abroad, both men of undisputed eminence in their technical fields, their range of contacts in government, academia, the armed forces, industry, and professional societies spanned the globe to an extent unparalleled then as now. Moreover, because they coordinated their activities closely, their combined influence far exceeded the sum of each one's individual contributions. This paper illustrates their personal origins as well as the foundations of their friendship, how their relationship became a professional alliance, and their joint impact on the world of aeronautics and astronautics during the twentieth century.

\section{SUBJECT TERMS}

Aeronautical history, Hugh L. Dryden, National Advisory Committee for Aeronautics (the NACA), Science advising, Theodore von Kármán

17. SECURITY CLASSIFICATION
OF REPORT
Unclassified

18. SECURITY CLASSIFICATION
OF THIS PAGE
Unclassified

19. SECURITY CLASSIFICATION
OF ABSTRACT
Unclassified

